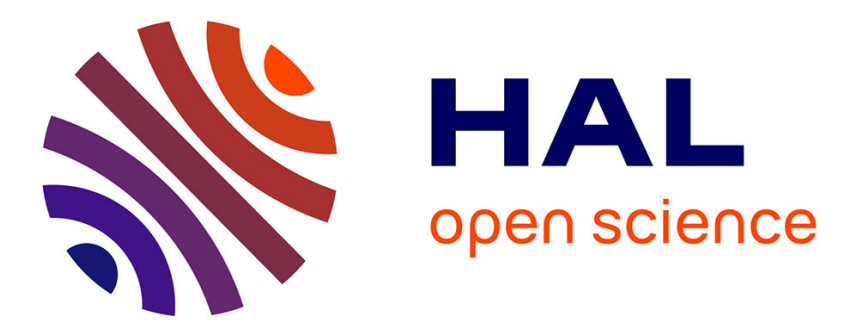

\title{
Manufacturing Research, Innovation, and PhD Education on a National Level - Produktion2030, a Swedish Example
}

\author{
Cecilia Warrol, Johan Stahre
}

\section{To cite this version:}

Cecilia Warrol, Johan Stahre. Manufacturing Research, Innovation, and PhD Education on a National Level - Produktion2030, a Swedish Example. IFIP International Conference on Advances in Production Management Systems (APMS), Sep 2015, Tokyo, Japan. pp.101-109, 10.1007/978-3-31922759-7_12 . hal-01431083

\section{HAL Id: hal-01431083 \\ https://hal.inria.fr/hal-01431083}

Submitted on 10 Jan 2017

HAL is a multi-disciplinary open access archive for the deposit and dissemination of scientific research documents, whether they are published or not. The documents may come from teaching and research institutions in France or abroad, or from public or private research centers.
L'archive ouverte pluridisciplinaire HAL, est destinée au dépôt et à la diffusion de documents scientifiques de niveau recherche, publiés ou non, émanant des établissements d'enseignement et de recherche français ou étrangers, des laboratoires publics ou privés.

\section{(c)(1)}

Distributed under a Creative Commons Attribution| 4.0 International License 


\title{
Manufacturing research, innovation, and PhD education on a national level - Produktion2030, a Swedish example
}

\author{
Cecilia Warrol $^{1}$ and Johan Stahre ${ }^{2}$ \\ ${ }^{1}$ Teknikföretagen - Association of Manufacturing industries, Sweden \\ cecilia.warrolateknikforetagen.se \\ ${ }^{2}$ Chalmers University of Technology, Sweden \\ johan.stahredchalmers.se
}

\begin{abstract}
National competitiveness in the manufacturing sector requires continuous investments in innovation, research, and education. Swedish manufacturing industry have joined forces with universities and research institutes to initiate Produktion2030, a successful public-private-partnership research and innovation programme. In this programme, industry is at the helm, to strengthen sustainable production and to increase investments towards advanced manufacturing in Sweden.
\end{abstract}

Keywords: Production, innovation, research, PhD education, Sweden.

\section{Introduction}

A competitive manufacturing industry is vital for Sweden's job market and growth. Similar economic dependencies may be found in most of the European countries, as well as in other global regions. This industrial sector is a foundation for a sustainable society and a key driver for new businesses and services; information and communication technology; and breakthrough manufacturing technologies e.g. additive manufacturing. Not surprisingly, governments globally are launching massive efforts, investing in manufacturing research, innovation, and education (RIE) programmes. Their goals are to increase global competitiveness in the manufacturing sector by stimulating e.g. innovation processes, business development, and technology transfer. In Europe, programmes like Finland's Fimecc; Germany's Industrie 4.0; Denmark's MADE; and the Smart Industry from the Netherlands are good examples of manufacturing innovation efforts. In Sweden, national manufacturing strategic research agendas [1] were established in 2008, 2011, and 2013. These initiatives were led by industry, in this case represented by Teknikföretagen ${ }^{1}$, together with the Swedish Production Academy and the national Research Institutes. As a result the national research and innovation programme Produktion $2030^{2}$ emerged. Its vision is that Swedish manufacturing industry stays a frontrunner and innovation leader in sustainable production. This paper presents the challenges, background, and operation of Produktion2030. The two authors of this paper are director and co-director of the Produktion2030 programme.

\footnotetext{
${ }^{1}$ Teknikföretagen (The Swedish Association of Engineering Industries), the main association for Sweden's export industry, representing 4000 companies. http://www.teknikforetagen.se

${ }^{2}$ The Produktion2030 research and innovations programme: http://www.produktion2030.se
} 


\section{Background - National Swedish efforts for manufacturing research, innovation, and $\mathrm{PhD}$ education}

Fifty percent of Sweden's export goods derive from the manufacturing sector and more than one million people are employed directly or indirectly by this sector. The Swedish reliance on industry has resulted in a long history of governmentally funded research and development programmes in the manufacturing area. In the 1960's and forward, technology- and processoriented research programs focusing on e.g. machining, welding, assembly, robotics, and materials have supported Swedish industrial excellence. In parallel, excellent organizational and work-science related research put Sweden in a leading position in how to organize and operate manufacturing operations. For practical reasons, the two inseparable organizational and technical strands merged in the 1990's. Also at that time, research projects became highly integrated between industry, academia, and institutes. Industrial co-funding requirements increased and the amount of governmental funding for manufacturing research started to drop, reaching a critically low level around 1995. The drop forced industry, academia, institutes, and research societies to protest strongly. Governmental funding agencies then launched sectororiented programmes to support more applied research in manufacturing (i.e. automotive, aerospace, etc.). Examples are the aerospace programme NFFP (1994-2008) and the automotive programmes MERA (2002 - 2007) and FFI (2008 - ongoing). In parallel, major Swedish research foundations launched manufacturing research efforts that focused on basic and applied research as well as national $\mathrm{PhD}$ education programmes, e.g. for product development (ENDREA 1996-2002) and production development (PROPER 1997-2004) [2] as well as ProViking (2002-2012).

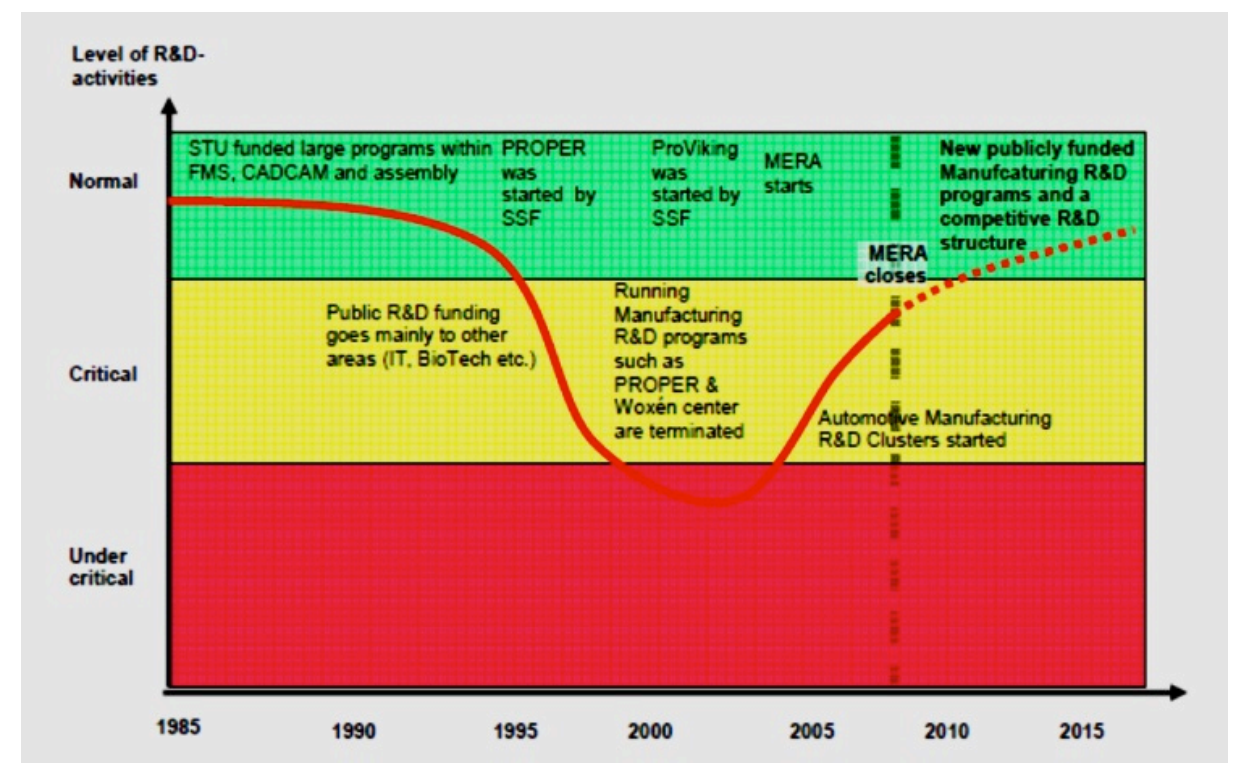

Figure 1. Swedish governmental research funding in production [3] 
The national project "Produktion för konkurrenskraft" (Production for Competitiveness) was launched by The Royal Swedish Academy of Engineering Sciences in 2004. The project was an important contribution to the reestablishment of a strong Swedish community for production research and development. The aim was to map Swedish academic and institute production research; to assess the R\&D needs of the manufacturing industry; and suggest actions to increase competitiveness of that industry. In 2007, Teknikföretagen ${ }^{1}$ took the lead in disseminating and promoting results from the project through a nation-wide tour, covering more than 100 Swedish cities. Recommendations were also submitted to the ministries Enterprise as well as Education \& Research in an industrial request for future research funding to universities and institutes. In addition, The Swedish Production Academy ${ }^{3}$, a national network for academic production engineering professors, was founded. All universities with engineering programmes and production research are members and the majority of $\mathrm{PhD}$ students are organized in the Production Academy Doctoral Chapter (PADOK). The Academy also hosts a bi-annual academic conference (Swedish Production Symposium) and constitutes a platform for long-term development of research and higher education.

\subsection{Consensus for a new innovation programme - Produktion2030}

The collaboration between industry (i.e. Teknikföretagen), the Swedish Production Academy, and the national manufacturing research institutes was established through joint efforts. Since 2005 , these actors had collaborated in promoting and developing national interest in production research, dissemination and education. To influence policy makers and put forward recommendations for research funding and education, these actors have produced national agendas for development in production, aiming to influence industry, academy and government. The first two agendas, "Svensk produktionsforskning 2020" and "Svensk produktion 2025" had impact on the Swedish Research and Innovation Bill in 2008, resulting in a radically increased government funding of 300 MSEK (M€ 30) within the production research area. A third strategic agenda, "Made in Sweden 2030" was presented in 2012. The agenda described a well-accepted roadmap for further governmental and industrial investments to renew a large number of industries, manufacturing industry included. Thus, the strategic research and innovation programme Produktion2030 was established in 2013.

The manufacturing industry in Sweden represents a majority of the national gross investments in $R \& D$, with more than a third of the total national spending on $R \& D$ deriving from the manufacturing industry. This makes Sweden highly dependent on its manufacturing industry for knowledge growth and innovation, as well as for job creation and growth. Government research and innovation policy directed towards the technology sector (e.g. manufacturing and engineering) has a huge impact on industry's investment's in manufacturing as well as R\&D. Regular surveys performed by Teknikföretagen confirms this.

Based on this discussion, Produktion2030 has the potential to fulfill the long-term goals of the programme, with increased investments in production in Sweden as a result. The programme also has a wider scope than its predecessors, encompassing the entire manufacturing sector.

\footnotetext{
${ }^{3}$ The Swedish Production Academy: http://www.produktionsakademien.com
} 


\section{Produktion2030 - a national programme for research, innovation and education}

Produktion2030 was one of five national Research and Innovation programmes launched in the first wave of Swedish Public-Private Partnerships in 2013. The government aim with the innovation programmes was to give industry, academy, and institute stakeholders considerable influence on the design and management of the research programme. Industrial leadership is crucial for the programmes' success. Challenges and research priorities are put forward from industry and the research community. Also, activities such as writing call texts, instigating dissemination activities and education programs are managed by the stake-holders through the programme management group.

Further and a bit unusual for this kind of programmes, the responsibility of the project portfolio is in the hands of the programme steering committee. The strategy and operation of the research programme is almost fully outsourced to its stake-holders. Instead, the programme will be assessed by the Swedish Government every three years. Thus, it will be up to industry and the research community in collaboration to make it successful. It should be noted that a continuous and mutual collaboration between Production2030 and VINNOVA, the funding agency, contributes to improvements and quality assurance of the programme.

Produktion2030 is organized in two main dimensions: 1) Six areas of strength, jointly identified by industry, academia, and institutes. 2) Five instruments, providing a scalable organizational infrastructure to facilitate operations.

\subsection{The Produktion2030 Areas of Strength}

Manufacturing is a wide thematic field with several possible dimensions. Research and innovation content may range from capturing of product customer needs to new ways for production system operation and maintenance. Digital tools for design and development of products have their corresponding potentials in digital visualization of production system for innovation and design. In a national context, there is natural distribution of interests and expertise among industry, academia, and research institutes.

In order to focus Produktion2030, parts of the strategic research agenda efforts were spent on identifying manufacturing areas where Sweden was already strong on research and innovation, and where a good potential for increased national competitiveness could be identified. Produktion2030 should be guided in the most relevant direction to achieve maximum impact in Swedish manufacturing industry. Therefore the scope of the research and innovation was structured into six areas. These areas were chosen through workshops, questionnaires, and bilateral discussions where representatives from research institutes, industry and academia took part. The findings were anchored with a large number of manufacturing companies with extensive research and production in Sweden, e.g. AB Volvo, SKF, ABB, Sandvik, and Saab Group. 
After several subsequent stages of analysis done in close collaboration between industry and researchers from academia and institutes, consensus was reached on the following six areas, which were to be developed as national Swedish areas of strength in manufacturing:

1. Environmentally sustainable and resource-efficient production

2. Flexible production

3. Virtual production development and simulation

4. Humans in the production system

5. Product- and production-based services

6. Integrated product- and production-development

The identified areas of strength correspond well to the prioritized research areas within the European public-private partnership (PPP) programme "Factories of the Future" which is aimed at enhancing the competitiveness of European industry [4]. The areas identified by the European PPP organization are: (i) Advanced manufacturing processes, (ii) Adaptive and smart manufacturing systems, (iii) Digital, virtual and resource-efficient factories, (iv) Collaborative and mobile enterprises, (v) Human-centred manufacturing and (vi) Customer-focused manufacturing.

\subsection{The Produktion2030 Instruments}

The operation of Produktion2030 is based on five "instruments", the second dimension of the programme, which provides a scalable and transparent organizational infrastructure. The vision of Produktion 2030 is that Sweden should be a front-runner in sustainable production and that investments in production in Sweden increase. Therefore, it takes more than investments in research and innovation projects to move forward.

The development of education related to national areas of strength, an increase of mobility between industry and research organizations and effective technology transfer to SMEs are important tools to reach the programme goals.

The operations of Produktion2030 are organized through the following five instruments:

1. Research and innovation projects: 0.5 to 3 year projects with a high Technology readiness level. Projects are initiated through consortia applications based on open calls for proposals twice a year. Sizes and formats of calls vary

2. Knowledge and technology transfer to small and medium sized enterprises (SMEs): captures and transfers method development, new knowledge and technology from the research and innovation projects to SMEs

3. Researcher and Industry Mobility: funding for short job exchanges for researchers in industry, universities and research institutes

4. Education: Produktion2030 has established a national $\mathrm{PhD}$-course programme and will develop courses on masters level as well as platforms for continuous education

5. Internationalization: major efforts to harmonize Swedish R\&I\&D programmes relevant for the manufacturing industry with EU programmes and funding.

The instruments have been constructed to create highest possible impact of the programme. Further, they are connected and slightly overlap in order to assure programme coherence. 
The findings and results from the Research and innovation projects are disseminated through the Knowledge and technology transfer instrument as well as through the Education instrument. The Mobility instrument has as main objective to support knowledge transfer within individual projects, thereby strengthening consortia and endorsing impact. Common to all instruments are the participations from the three types of stakeholders: industry, academy and research institutes. Each instrument has a designated manager (or management group), reporting to the Programme Office.

Sweden is among the leading countries in the world when it comes to investments in research, with typically $3 \%$ of GDP invested annually from private and public sectors. In addition, Sweden ranks among the foremost countries when it comes to innovation. In contrast, only a small portion of these investments in research and innovation are turned over into business creation or added value for industry. The void between research and the private business sector, known as the "Valley of death" [5], is challenging governments all over the world, and great efforts are made to create innovation and research programmes that can minimize this gap and build supporting infrastructures that make more use of research in the business community.

Produktion2030 is aiming to construct a reliable infrastructure that connects research and business through primarily three of its five instruments. The instrument "Research and innovation projects" typically invests in projects that result in test-beds and demonstrators which provides opportunities to try results in an industrial setting. Through this approach an industrial impact is achieved and the companies in the project consortia can attain imminent results to challenges and needs put forward in the project. The instrument "Knowledge and technology transfer to SME's" is designed to increase the use of test-beds and demonstrators far beyond the limited numbers of companies in a consortia. The instrument aims to extend the reach of each project by re-packaging them to fit a wider group of companies, typically SME's that are subcontractors to the manufacturing sector. Each project is offered a small top-up funding to create a simplified, shorter version, and already after two years the results are very promising. To support this dissemination, the manager of the instrument is working in partnership with a large number of clusters and SME-associations within the manufacturing sector. The "Mobility" instrument supports the implementation of results from the research and innovation projects by targeting the project consortia. This instrument provides the opportunity to achieve a more thorough testing or implementation of results by making shorter job exchanges between the consortia partners possible (e.g. representatives from industry and research).

The fourth instrument "Education", is in a way involving industry by directing its offerings of courses and continuous education programmes to members of industry as well as to representatives of academia and research institutes, in this way networks between industry and research organizations are created. Expert Groups as well as the Steering Committee can during the course of the programme suggest topics and knowledge trends that are then addressed by the Education instrument.

Internationalization, the fifth and last instrument directs much of its efforts to increase industry involvement in European funded projects, as well as positioning challenges for Swedish industry and research community high on the agenda for European research programmes and platforms. 
Industry commitment is an important KPI of the success of Produktion2030 and the principal organization, Teknikföretagen, together with the funding agency VINNOVA, is expecting a fifty-fifty co-financing of the programme as a whole. To date, after two years in operation, we find that this goal has been surpassed, as every instrument and activity has an average industry participation more than $50 \%$.

\subsection{The organization of the Produktion2030 programme}

The organization and communication flows in Produktion2030 are shown in Figure 2. The programme has a bottom up (described in fig. 2 as a left to right flow) approach where ideas, vision, challenges and project proposals are suggested by members of industry, academy and research institutes, organized in Expert Groups. The groups form communities for national special interest in production, specifically in the corresponding area of strength. The groups have a strong commitment to identify challenges and opportunities in production development and innovation.

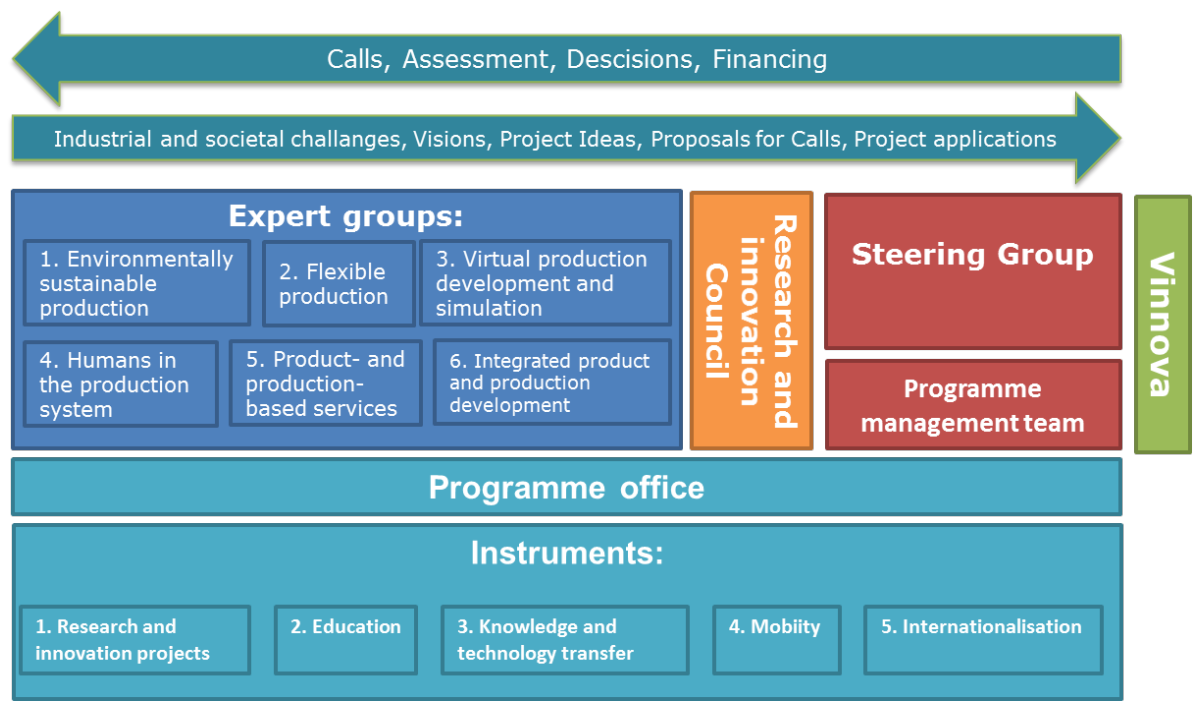

Figure 2. Produktion2030 Organizational structure

There are currently around 200 persons involved in the Expert Groups. Each Group is managed by two Expert Group Leaders, who have been selected among young (i.e. less than 45 years) and promising academic researchers in each area of strength.

The proposals are passed on to the Research and Innovation Council, a smaller group of 1012 people representing industry, academy and institutes, with the task to discuss and prioritize the wide range of proposals coming from the Expert Groups. The third level in the decision process is the Steering Committee of 10 people, which has the power of decision, working towards the goals set up in the programme. The Expert Groups gather at least two times per year with the assignment to identify challenges related to production industry, including needs in education, test beds and demonstrators. 


\section{Discussion and conclusions}

Manufacturing excellence is of vital importance for an export-dominated country like Sweden. Being a nation of only close to 10 million people, strong national collaboration and consensus between industries, universities, institutes, Government, and funding institutions need to be sought to maintain a high level of excellence in the research and education and to attract increased investments in production activities.

The aim of the Produktion2030 public-private partnership (PPP) programme is to invest and leverage a limited amount of government funding towards a maximum impact on the manufacturing industry, production research, and education. The results in technology developments and innovations production will have an influence on investment in production in Sweden as well as supporting Swedish efforts to be a front runner in production.

This paper has presented a series of national Swedish programme efforts. It has also exemplified how a national programme for research, innovation and $\mathrm{PhD}$ education can be designed and operated to achieve a high level of national involvement and consensus on aim, vision and direction.

\section{Acknowledgments}

The authors would like to express their gratitude to the Swedish agency for innovation systems, VINNOVA for funding our work. We extend our gratitude to the Swedish Foundation for Strategic Research (SSF) (http://www.stratresearch.se/en/) for the extensive and absolutely critical support of the following three research programmes for production engineering and product development, i.e. PROPER [2] (1997-2004), ENDREA, and ProViking (2002-2013). We would also like to thank The Royal Swedish Academy of Engineering Sciences (IVA) (http://www.iva.se/iva-in-english/) for establishing the national project "Produktion for konkurrenskraft" (2004-2005) which served as a joining force for Swedish industry, academia, and institutes towards multiple national research agendas and eventually the Produktion2030 programme. Finally, we would like to acknowledge the importance for the development a Swedish research and innovation infrastructure of the efforts made by the professors of the Swedish Production Academy; the industry experts at Teknikföretagen; and the researchers at Swerea IVF representing the Swedish research institute sector.

\section{References}

1. Teknikföretagen: Made in Sweden - Strategic Research Agenda, Teknikföretagen publications (2013)

2. Johansson, C, Stahre, J., Rosén, B.G.: Production Engineering Research and Education PROPER Final report 1997-2004, Chalmers University of Technology, Sweden. (2005)

3. Hjelm, S.: Manufacturing research funding in Sweden, Internal report, Scania (2015)

4. European Commission: Factories of the future - Multi-annual roadmap for the contractual ppp under horizon 2020, Luxembourg: Publications Office of the European Union, ISBN 978-92-79-31238-0 (2013)

5. Auerswald, P.E. and Branscomb, L.M.: Valleys of Death and Darwinian Seas: Financing the Invention to Innovation Transition in the United States, The journal of technology transfer, Vol. 28:3-4, pp 227-239 (2003) 